\title{
Harvesting methods on physical and physiological quality of Panicum maximum seeds
}

\author{
Carla G. Machado ${ }^{1}$, Simério C. S. Cruz ${ }^{1}$, Givanildo Z. Silva ${ }^{1}$, \\ Luciana C. Carneiro ${ }^{1} \&$ Ingrid M. H. de L. Silva ${ }^{1}$ \\ ${ }^{1}$ Universidade Federal de Goiás/Regional de Jataí. Jataí, GO, Brasil. E-mail: carlagomesmachado@gmail.com - ORCID: 0000-0001-5535-1586; \\ simerio_cruz@yahoo.com.br - ORCID: 0000-0002-6327-8590; givanildozildo@hotmail.com (Corresponding author) - ORCID: 0000-0002-6380- \\ 1599; luciana.celeste.carneiro@gmail.com - ORCID: 0000-0003-1829-2075; ingridm_hungria@hotmail.com - ORCID: 0000-0002-6422-6098
}

\begin{abstract}
The quality of seeds of forage species can be influenced by the different harvesting methods used. The aim of this study was to evaluate the physical and physiological quality of seeds of Panicum maximum, cultivars 'Massai' and 'Mombaça', obtained by the methods of ground sweeping and direct heading (cutting of the panicles) of different farmers in the year 2014. The test consisted of three lots of each cultivar from seed farmers in the state of Goiás, Brazil. The experimental design was completely randomized, in $3 \times 2$ factorial scheme (farmer $\mathrm{x}$ harvesting methods) with four replicates. The following variables were analyzed: physical purity, 1000-seed weight; germination and first count of germination. At the end of the germination the percentage of dormancy and dead seeds were evaluated by the tetrazolium test of the remaining seeds, in addition to the abnormal seedlings. The data were submitted to analysis of variance and the means of the treatments were compared by Tukey test at 0.05 probability level. Seeds of $P$. maximum 'Massai' and 'Mombaça' collected by ground sweeping have superior physiological quality despite the low level of purity of the lots, compared to direct heading method.
\end{abstract}

Key words: forage grasses, guineagrass, physical purity, ground sweeping

\section{Métodos de colheita na qualidade física e fisiológica de sementes de Panicum maximum}

RESUMO: A qualidade de sementes de espécies forrageiras pode ser influenciada pelos diferentes métodos de colheita utilizados. Nesta pesquisa objetivou-se avaliar a qualidade física e fisiológica de sementes de Panicum maximum cultivares Massai e Mombaça, obtidas pelos métodos de colheita no cacho (corte das panículas) e varredura do solo, de diferentes produtores no ano de 2014 . O ensaio constituiu-se de três lotes de cada cultivar oriundas de produtores de sementes do Estado de Goiás, Brasil. O delineamento experimental utilizado foi o inteiramente casualizado em esquema fatorial $3 \times 2$ (produtor x método de colheita) com quatro repetições. Foram avaliadas: pureza física, massa de mil sementes; germinação e primeira contagem de germinação. Ao final do teste foram avaliadas as porcentagens de sementes dormentes e mortas, pelo teste de tetrazólio das sementes remanescentes, além das plântulas anormais. Após a obtenção dos dados, os mesmos foram submetidos à análise de variância e as médias dos tratamentos foram comparadas pelo teste de Tukey, a 0,05 de probabilidade. As sementes de P. maximum cultivares Massai e Mombaça colhidas por varredura do solo tem melhor qualidade fisiológica, apesar do baixo nível de pureza dos lotes quando comparadas à colheita no cacho.

Palavras-chave: gramínea forrageira, capim colonião, pureza física, varredura do solo 


\section{INTRODUCTION}

In Brazil, there are approximately 172 million hectares of cultivated pastures in extensive livestock farming systems (Timbó et al., 2014), ranking the country as the largest producer, consumer and exporter of forage seeds in the world (Vigna et al., 2011; Beling, 2016).

Panicum maximum (Jacq.) stands out among forage grasses, being used to form pastures in tropical regions of Brazil and other countries of America and Africa, because it is tolerant to drought, and as a result, the demand for seeds of the cultivar 'Mombaça' has been so expressive (Reynoso et al., 2009; Canto et al., 2012; Mendonça et al., 2014; Melo et al., 2016a).

The cultivar 'Massai' is a hybrid originated from the cross between $P$. maximum and $P$. infestum native to Africa and stands out for its high capacity to produce leaves and tillers, with fast regrowth after cutting or grazing, being a promising grass species for small animal production systems (Lopes et al., 2013; Vargas Junior et al., 2013).

Seeds of tropical forage grasses are mostly collected by ground sweeping, which consists in the recovery of seeds fallen on the soil after dehiscence, hence they have low purity. The opposite is observed in the harvesting from the panicles (direct heading), which has high purity level (Maschietto et al., 2003; Quadros et al., 2012). On this aspect, there is already a study conducted by Maschietto et al. (2003) evaluating harvesting methods and quality of $P$. maximum seeds, cultivar 'Mombaça'. Nevertheless, new studies are necessary because the purity levels found by the authors are below the current ones observed in the studies of Melo et al. (2016a, b), since the producers are improving to meet marketing requirements.

In the present study, the objective was to evaluate the physical and physiological quality of seeds of Panicum maximum, cultivars 'Mombaça' and 'Massai', obtained from different producers and harvested by the methods of direct heading and ground sweeping.

\section{Material ANd Methods}

Seeds were obtained from three producers in the municipality of Quirinópolis - Goiás, in 2014, through a seed producing company that provided one seed lot of each producer, who used two harvesting methods (direct heading and ground sweeping), which consisted individual experiments for each cultivar.

Direct heading was carried out when the panicles had $30 \%$ of dehiscence, which were cut and threshed in combine harvester. Panicles harvested by the direct heading method remained piled in the field for three to five days, for curing and subsequent beating. Artificial drying was carried out in an open field, only with seeds harvested from the panicles, until reaching the moisture content (12\%) similar to that of seeds obtained by ground sweeping.

For seeds harvested by a ground-sweeping harvester, plants were cut by a mower blade and windrowed. The harvester swept the surface earth mixed with the seeds into its interior, where this material was ventilated and sieved to remove part of the impurities mixed to the seeds. Still in the field, the collected mixture of seeds and earth was subjected to a pre-cleaning in a cylindrical-sieve machine connected to the power take-off of the tractor.

Immediately after, for each lot of raw seed, $5 \mathrm{~kg}$ samples were collected, homogenized, placed in single-layer paper package and taken to the Seed Laboratory of the Federal University of Goiás - Jataí Regional Unit.

At the laboratory, seeds were homogenized using a Solotype divider, passing three times through the device and divided by the method of constant divisions until obtaining the working sample for purity analysis, which consisted of two $2 \mathrm{~g}$ subsamples weighed on precision scale $(0.001 \mathrm{~g})$. To obtain the portion of pure seeds, the separation was complemented by manual collection and the results were expressed in percentage (Brasil, 2009). At the end of this procedure, moisture content was determined by the oven method at $105 \pm 3{ }^{\circ} \mathrm{C}$ for $24 \mathrm{~h}$ (Brasil, 2009).

Physical purity determination (\%) and physiological quality evaluation of pure seeds (germination and first count of germination) were carried out according to the Norms for Seed Analysis (Brasil, 2009).

The germination test was carried out with four replicates of 50 seeds, distributed in transparent plastic boxes $(11.0 \mathrm{x}$ $11.0 \times 3.5 \mathrm{~cm}$ ), on two sheets of filter paper, moistened with a water volume equivalent to two times their dry weight, and kept under temperature regime of $15-35{ }^{\circ} \mathrm{C}$. Germination percentage was evaluated at 10 and 28 days after the test began. At 28 days, the percentages of abnormal seedlings were also evaluated (Brasil, 2009).

Concomitantly with the germination test, the first count of germination was evaluated by counting the normal seedlings at 10 days, expressed in percentage (Brasil, 2009).

After the germination test, the remaining seeds were subjected to tetrazolium test to identify dormant and dead seeds. These seeds were cut in the middle region and longitudinally through the embryo, and one of the halves was immersed in $0.1 \%$ tetrazolium solution at $30 \pm 3{ }^{\circ} \mathrm{C}$ for $2 \mathrm{~h}$ in the absence of light (Cardoso et al., 2014). After this period, the seeds were washed in distilled water, readings were immediately taken, and the seeds were classified as viable (dormant) and unviable (dead) (Brasil, 2009).

The test was conducted in a completely randomized experimental design in $3 \times 2$ factorial scheme (producer $\mathrm{x}$ harvesting method) in four replicates. After obtaining the data, they were transformed to $(x+0.5)^{1 / 2}$ for parameters with values equal to zero, as recommended by Banzatto \& Kronka (2006), but the means presented in the tables come from the original data. Transformed data were subjected to analysis of variance and treatment means were compared by Tukey test at 0.05 probability level.

\section{Results AND Discussion}

The moisture contents in the seeds of Panicum maximum, cultivars 'Massai' and 'Mombaça', were lower in those harvested by ground sweeping (9.79 and 9.89\%, respectively), while seeds harvested by direct heading showed levels of 10.21 and $10.31 \%$, respectively. 
Lower moisture content in seeds collected from the soil may be explained by the fact that the fruits are dehiscent and the environmental conditions allowed such difference. When seeds reach physiological maturity, the mother plant no longer has any control over seed moisture content (Carvalho \& Nakagawa, 2012).

In the description of the physiological quality of $P$. maximum seeds, it could be noted that the purity level of seeds harvested by direct heading was higher than that of seeds harvested by ground sweeping for both cultivars (Figures 1A and $\mathrm{B}$ ). According to the Normative Instruction No. 30 of the Ministry of Agriculture, Livestock and Food Supply (MAPA), the minimum standard of physical purity for the marketing of certified seeds of P. maximum is 50\% (Brasil, 2008); therefore, based exclusively on the characteristics of purity, only the lot of 'Massai' grass seeds from producer 2 harvested by ground sweeping would not be in condition of being commercialized in the national market.

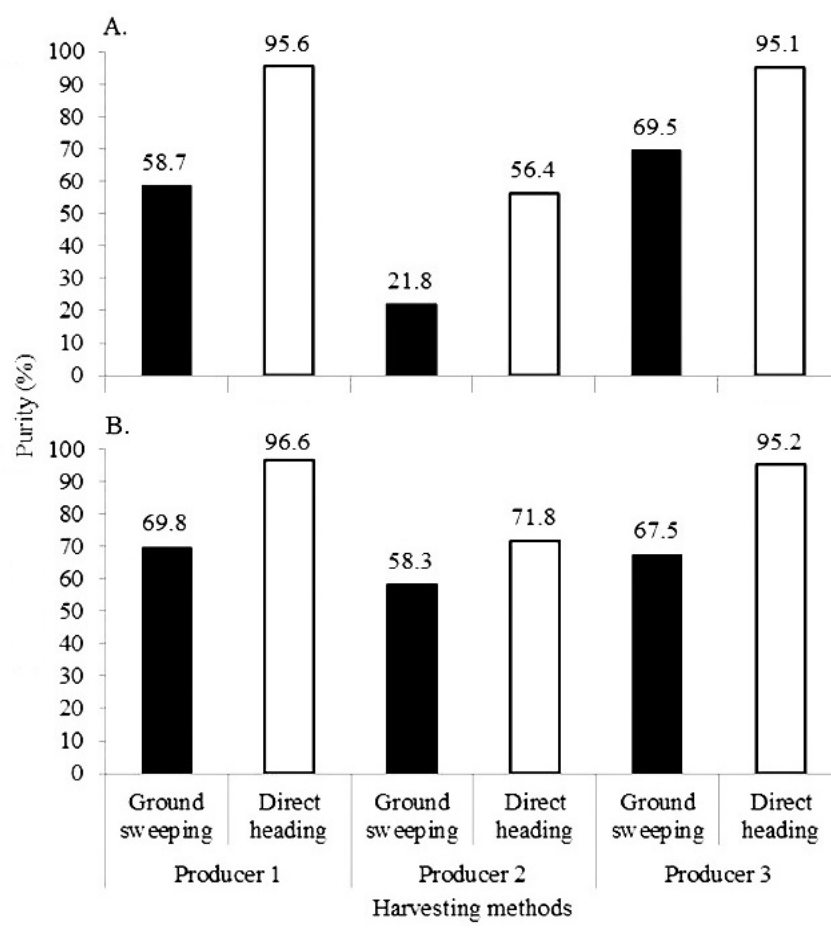

Figure 1. Percentage of physical purity of Panicum maximum seeds, cultivars 'Massai' (A) and 'Mombaça' (B), obtained from three producers and by two harvesting methods
According to Maschietto et al. (2003), seeds harvested by the direct heading method have purity levels higher compared to those harvested by ground sweeping, and the impurities are fundamentally of plant origin. This type of impurity is lighter than earth and more easily eliminated during the processing, which does not occur in the harvest by ground sweeping.

In addition, these seeds after harvest would be subjected to processing to be able to be commercialized, and these values could increase. As observed by Melo et al. (2016a, b) for $P$. maximum cultivars 'Mombaça' and Tanzania, processing is necessary to meet the requirements of purity and germination established by the standards of national commercialization of seeds.

Table 1 presents the results of the analysis of variance for the data of the evaluated parameters referring to the harvesting methods and three producers of $P$. maximum seeds, cultivars 'Massai' and 'Mombaça'. In both cultivars, there was interaction between factors for the variables analyzed, except the cultivar 'Massai', with interaction only for 1000-seed weight and dead seeds.

Higher 1000-seed weight for the cultivar 'Massai' (Table 2) was obtained by the harvesting method of ground sweeping, compared to direct heading. In the comparison among producers for sweeping method, the weight of seeds from producer 3 was superior to the others, with value of $1.34 \mathrm{~g}$. For harvest by direct heading, the lowest weight was obtained in seeds from producer 2, $0.60 \mathrm{~g}$.

The values of 1000-seed weight for seeds obtained by ground sweeping in the present study were similar to those found by Melo et al. (2018), in a study on the processing of 'Massai' grass seeds. The weight difference between methods is mainly due to the predominance of mature seeds in the

Table 2. 1000-seed weight, and dead seeds of Panicum maximum cultivar 'Massai' obtained from three producers and by two harvesting methods

\begin{tabular}{cccccc}
\hline \multirow{3}{*}{ Producer } & \multicolumn{4}{c}{ Harvesting methods } \\
\cline { 2 - 3 } & $\begin{array}{c}\text { Ground } \\
\text { sweeping }\end{array}$ & $\begin{array}{c}\text { Direct } \\
\text { heading }\end{array}$ & & $\begin{array}{c}\text { Ground } \\
\text { sweeping }\end{array}$ & $\begin{array}{c}\text { Direct } \\
\text { heading }\end{array}$ \\
\cline { 2 - 3 } \cline { 5 - 6 } 1 & $\mathbf{1 0 0 0}$-seed weight (g) & & \multicolumn{2}{c}{ Dead seeds (\%) } \\
2 & $1.12 \mathrm{bA}$ & $0.74 \mathrm{aB}$ & & $6 \mathrm{aB}$ & $30 \mathrm{aA}$ \\
3 & $1.13 \mathrm{bA}$ & $0.60 \mathrm{bB}$ & & $2 \mathrm{aB}$ & $41 \mathrm{aA}$ \\
\hline & $1.34 \mathrm{aA}$ & $0.70 \mathrm{aB}$ & & $8 \mathrm{aB}$ & $28 \mathrm{bA}$ \\
\hline
\end{tabular}

Means followed by the same letter, lowercase in the column and uppercase in the row, do not differ statistically by Tukey test at 0.05 probability level

Table 1. Analysis of variance for 1000-seed weight, germination, first count, abnormal seedlings, dormant and dead seeds of Panicum maximum, cultivars 'Massai' and 'Mombaça', obtained from three producers and by two harvesting methods

\begin{tabular}{|c|c|c|c|c|c|c|c|}
\hline Factors & $\begin{array}{l}\text { Degree of } \\
\text { treedom }\end{array}$ & $\begin{array}{c}1000 \text {-seed } \\
\text { weight }\end{array}$ & Germination & First count & $\begin{array}{l}\text { Abnormal } \\
\text { seedlings }\end{array}$ & $\begin{array}{c}\text { Dormant } \\
\text { seeds }\end{array}$ & Dead seeds \\
\hline \multicolumn{8}{|c|}{ Panicum maximum cultivar Massai } \\
\hline Producer (P) & 2 & $0.05^{\star \star}$ & $654.64^{\star \star}$ & $796.19 * *$ & $227.10^{*}$ & $2.488 .17^{\star \star}$ & $1.26^{\text {ns }}$ \\
\hline Harvesting method (HM) & 1 & $1.60 * \star$ & $5,642.49 * *$ & $5,721.89 * *$ & $632.17^{\star \star}$ & $2,604.17^{* *}$ & $3,350.72 * *$ \\
\hline $\mathrm{P} \times \mathrm{HM}$ & 2 & $0.03^{\star \star}$ & $15.08^{\text {ns }}$ & $45.55^{\text {ns }}$ & $34.35^{\mathrm{ns}}$ & $13.17^{\mathrm{ns}}$ & $162.44^{*}$ \\
\hline Residue & 18 & 0.002 & 17.38 & 14.19 & 52.06 & 15.49 & 37.48 \\
\hline CV $(\%)$ & & 4.60 & 15.81 & 15.03 & 44.37 & 15.49 & 26.64 \\
\hline \multicolumn{8}{|c|}{ Panicum maximum cultivar Mombaça } \\
\hline Producer $(\mathrm{P})$ & 2 & $0.01 * *$ & $12.05^{\star *}$ & $11.11^{\star * *}$ & $25.62^{\star *}$ & $10.74^{* *}$ & $10.48^{* *}$ \\
\hline Harvesting method (HM) & 1 & $0.39 * *$ & $29.33^{* *}$ & $21.15^{\star \star}$ & $61.92^{* *}$ & $15.63^{* *}$ & $63.76^{\star \star}$ \\
\hline $\mathrm{P} \times \mathrm{HM}$ & 2 & $0.02^{\star *}$ & $6.84^{\star \star}$ & $9.08^{\star \star}$ & $15.47^{\star \star}$ & $11.62^{\star \star}$ & $7.22^{\star \star}$ \\
\hline Residue & 18 & 0.01 & 0.34 & 0.63 & 0.64 & 0.36 & 0.47 \\
\hline CV $(\%)$ & & 1.02 & 22.59 & 33.25 & 20.92 & 8.49 & 17.85 \\
\hline
\end{tabular}

***, ns Significant at 0.05 probability level, significant at 0.01 probability level and not significant by $\mathrm{F}$ test, respectively 
harvest by ground sweeping, which had dehiscence of the panicle, whereas immature and lighter seeds prevail in the heads, a fact also observed by Maschietto et al. (2003) for the cultivar 'Mombaça'.

Still in Table 2, lower percentage of dead seeds harvested by ground sweeping probably occurred because these seeds had completed their maturation process, whereas those harvested by direct heading were mostly immature, having no conditions to later complete the germination process.

The variables analyzed in the cultivar 'Massai' which had no correlations between harvesting methods and producer (Table 1) are presented in Table 3.

Seeds obtained from producer 2 and by ground sweeping had higher percentages of germination and vigor according to the first count, and lower percentage of dormant seeds. However, they had higher percentage of abnormal seedlings, probably because seeds collected from the soil had already completed maturation and, therefore, had better physiological quality and lower dormancy.

The occurrence of dormancy in commercial lots of seeds from forage grasses, such as the genus Panicum, was minimized by the adoption of ground sweeping as the harvesting method. This method allows seeds to complete their maturation and remain on the soil exposed to environmental action until being collected. After this procedure, some time is still required until seeds are available at the market (Tomaz et al., 2015; Melo et al., 2016a, b; Silva et al., 2017; Melo et al., 2018).

The high percentage of abnormal seedlings was probably due to the deterioration of the seeds, which completed first their maturation, consequently falling on the soil, and were exposed to environmental conditions for a longer time.

It is known that seed physiological potential is variable between seed lots, between seeds of the same lot and even between parts of the same seed, because of the differences in the deterioration rate, due to the chemical composition of the

Table 3. Germination, first count, abnormal seedlings and dormant seeds of Panicum maximum cultivar 'Massai' obtained from three producers and by two harvesting methods

\begin{tabular}{|lcccccc}
\hline \multirow{2}{*}{ Variables } & \multicolumn{3}{c}{ Producer } & & \multicolumn{2}{c}{ Harvesting methods } \\
\cline { 2 - 4 } \cline { 6 - 7 } & $\mathbf{1}$ & $\mathbf{2}$ & $\mathbf{3}$ & & $\begin{array}{c}\text { Ground } \\
\text { sweeping }\end{array}$ & $\begin{array}{c}\text { Direct } \\
\text { heading }\end{array}$ \\
\hline Germination (\%) & $23 \mathrm{~b}$ & $37 \mathrm{a}$ & $15 \mathrm{c}$ & & $45 \mathrm{a}$ & $6 \mathrm{~b}$ \\
First count (\%) & $23 \mathrm{~b}$ & $37 \mathrm{a}$ & $12 \mathrm{c}$ & & $43 \mathrm{a}$ & $5 \mathrm{~b}$ \\
Abnormal seedlings (\%) & $8 \mathrm{ab}$ & $15 \mathrm{a}$ & $7 \mathrm{~b}$ & & $15 \mathrm{a}$ & $5 \mathrm{~b}$ \\
\hline Dormant seeds (\%) & $52 \mathrm{a}$ & $27 \mathrm{~b}$ & $60 \mathrm{a}$ & & $36 \mathrm{~b}$ & $57 \mathrm{a}$ \\
\hline
\end{tabular}

Means followed by the same letter in the line do not differ statistically by Tukey test at 0.05 probability level reserves stored in the seeds and to the environment (Silva et al., 2014) and, in the case of the present study, because the seeds which initially fell on the ground remained stored in the field.

Table 4 describes the variables resulting from the interaction between producers of 'Mombaça' grass and harvesting methods. For 1000-seed weight, as observed in 'Massai' grass, higher weights were obtained in seeds collected by ground sweeping. For this method, seeds obtained from producers 2 and 3 had higher physiological quality.

Seeds from producers 1 and 2, collected by ground sweeping, had higher percentage of germination and abnormal seedlings. For the first count, only seeds from producer 1 and the ground sweeping method had higher percentage and there was no difference of the variable between the harvesting methods for the others.

Germination below $40 \%$ was observed and this is the minimum value required for the marketing of 'Mombaça' grass seeds (Brasil, 2008). For producers 1 and 2 with seeds collected by ground sweeping, the low germination is due to high incidence of abnormal seedlings, probably, as previously mentioned, resulting from the deterioration of seeds which naturally fell and were deposited on the soil, being exposed to weather conditions for a longer time.

For the producers 2 and 3 with harvest by direct heading and producer 3 with harvest by ground sweeping and direct heading, low-quality seeds are due to high incidence of dormant and dead seeds. Probably, these seeds were immature when harvested and, therefore, did not complete their germination process; another aspect may be the high level of dormancy immediately after harvest.

Dormancy may vary within the same cultivated species, as observed here, and its cause may be related to more than one factor, such as production system, harvest, edaphoclimatic conditions, seed processing and storage conditions, and the mechanism of dormancy has particularities, which hamper any generalization on its causes (Cardoso et al., 2014)

Higher percentage of dead seeds for producer 3 when they were harvested by ground sweeping occurred because this method leads to greater mechanical damage, due to the various operations (cut, windrowing and sweeping) occurred on the seeds shattered on the ground. These seeds may also be damaged by pests and climatic processes in the field, since they are directly exposed on the soil. In addition, according to Carvalho \& Nagakawa (2012), the permanence of seeds in the field, after physiological maturity, is a condition that leads to deterioration and loss of vigor and viability.

Table 4. 1000-seed weight, germination first count, abnormal seedlings, dormant and dead seeds of Panicum maximum cultivar 'Mombaça' obtained from three producers and by two harvesting methods

\begin{tabular}{|c|c|c|c|c|c|c|c|c|c|c|c|c|}
\hline \multirow{4}{*}{ Producer } & \multicolumn{12}{|c|}{ Harvesting methods } \\
\hline & $\begin{array}{l}\text { Ground } \\
\text { sweeping }\end{array}$ & $\begin{array}{c}\text { Direct } \\
\text { heading }\end{array}$ & $\begin{array}{l}\text { Ground } \\
\text { sweeping }\end{array}$ & $\begin{array}{c}\text { Direct } \\
\text { heading }\end{array}$ & $\begin{array}{l}\text { Ground } \\
\text { sweeping }\end{array}$ & $\begin{array}{c}\text { Direct } \\
\text { heading }\end{array}$ & $\begin{array}{l}\text { Ground } \\
\text { sweeping }\end{array}$ & $\begin{array}{c}\text { Direct } \\
\text { heading }\end{array}$ & $\begin{array}{l}\text { Ground } \\
\text { sweeping }\end{array}$ & $\begin{array}{c}\text { Direct } \\
\text { heading }\end{array}$ & $\begin{array}{l}\text { Ground } \\
\text { sweeping }\end{array}$ & $\begin{array}{c}\text { Direct } \\
\text { heading }\end{array}$ \\
\hline & \multicolumn{2}{|c|}{1000 -seed weight } & \multicolumn{2}{|c|}{ Germination } & \multicolumn{2}{|c|}{ First count } & \multicolumn{2}{|c|}{ Abnormal seedlings } & \multicolumn{2}{|c|}{ Dormant seeds } & \multicolumn{2}{|c|}{ Dead seeds } \\
\hline & \multicolumn{2}{|c|}{$(\mathrm{g})$} & \multicolumn{10}{|c|}{$(\%)$} \\
\hline 1 & $1.31 \mathrm{bA}$ & $0.85 \mathrm{aB}$ & $25 \mathrm{aA}$ & $0 \mathrm{bB}$ & $25 \mathrm{aA}$ & $0 \mathrm{bB}$ & $60 \mathrm{aA}$ & $2 \mathrm{bB}$ & $15 \mathrm{cB}$ & $67 \mathrm{aA}$ & $1 \mathrm{bB}$ & $31 \mathrm{aA}$ \\
\hline 2 & $1.46 \mathrm{aA}$ & $0.58 \mathrm{bB}$ & $18 \mathrm{aA}$ & $9 \mathrm{aB}$ & $14 \mathrm{bA}$ & $4 \mathrm{aA}$ & $41 \mathrm{aA}$ & $15 \mathrm{aB}$ & $40 \mathrm{bA}$ & $51 \mathrm{aA}$ & $1 \mathrm{bB}$ & $26 \mathrm{aA}$ \\
\hline 3 & $1.46 \mathrm{aA}$ & $0.88 \mathrm{aB}$ & $3 \mathrm{bA}$ & $0 \mathrm{bB}$ & $2 \mathrm{cA}$ & $0 \mathrm{bA}$ & $5 \mathrm{bA}$ & $2 \mathrm{bA}$ & $72 \mathrm{aA}$ & $66 \mathrm{aA}$ & $21 \mathrm{aB}$ & $32 \mathrm{aA}$ \\
\hline
\end{tabular}

Means followed by the same letter, lowercase in the column and uppercase in the row, do not differ statistically by Tukey test at 0.05 probability level 
Seeds collected from the soil have higher germination because in most cases they are fully mature, whereas for the harvest by direct heading the quantity of immature seeds is more expressive (Maschietto et al., 2003).

\section{Conclusion}

Seeds of Panicum maximum cultivars 'Massai' and 'Mombaça' harvested by ground sweeping have better physiological quality, despite the low purity level of the lots compared to the harvest by direct heading.

\section{Literature Cited}

Banzatto, D. A.; Kronka, S. N. Experimentação agrícola. 4.ed. Jaboticabal: FUNEP, 2006. 237p.

Beling, R. R. Anuário brasileiro de sementes. Santa Cruz do Sul: Editora Gazeta, 2016. 72p.

Brasil. Ministério da Agricultura, Pecuária e do Abastecimento. Instrução Normativa n 30, de 21 de maio de 2008. Brasília: Diário Oficial da União, 2008. 45p. Seção 1

Brasil. Ministério da Agricultura, Pecuária e do Abastecimento. Regras para análise de sementes. Brasília: MAPA, 2009. 395p.

Canto, M. W. do; Barth Neto, A.; Pancera Júnior, E. J.; Gasparino, E.; Boleta, V.S. Produção e qualidade de sementes do capim-mombaça em função da adubação nitrogenada. Bragantia, v.71, p.430-437, 2012. https://doi.org/10.1590/S0006-87052012005000032

Cardoso, E. D.; Sá, M. E. de; Haga, K. I.; Binotti, F. F. da S.; Nogueira, D. C.; Valério Filho, W. V. Desempenho fisiológico e superação de dormência em sementes de Brachiaria brizantha submetidas a tratamento químico e envelhecimento artificial. Semina: Ciências Agrárias, v.35, p.21-38, 2014. https://doi.org/10.5433/1679$0359.2014 \mathrm{v} 35 \mathrm{n} 1 \mathrm{p} 21$

Carvalho, N. M. de; Nakagawa, J. Sementes: Ciência, tecnologia e produção. 5.ed. Jaboticabal: FUNEP, 2012. 590p.

Lopes, M. N.; Cândido, M. J. D.; Pompeu, R. C. F. F.; Silva, R. G. da; Lopes, J. W. B.; Fernandes, F. R. B.; Lacerda, C. F. de; Bezerra, F. M. L. Fluxo de biomassa em capim-massai durante o estabelecimento e rebrotação com e sem adubação nitrogenada. Revista Ceres, v.60, p.363-371, 2013. https://doi.org/10.1590/ S0034-737X2013000300009

Maschietto, R. W.; Novembre, A. D. da L. C.; Silva, W. R. da. Métodos de colheita e qualidade das sementes de capim colonião cultivar Mombaça. Bragantia, v.62, p.291-296, 2003. https://doi. org/10.1590/S0006-87052003000200015

Melo, L. F. de; Martins, C. C.; Silva, G. Z. da; Boneti, J. E. B.; Vieira, R. D. Beneficiamento na qualidade física e fisiológica de sementes de capim-mombaça. Revista Ciência Agronômica, v.47, p.667674, 2016a.
Melo, L. F. de; Martins, C. C.; Silva, G. Z. da; Pereira, F. E. C. B.; Jeromini, T. S. Effects of processing phases on the quality of massai grass seeds. Revista Ciência Agronômica, v.49, p.259-266, 2018.

Melo, L. F. de; Martins, C. C.; Silva, G. Z. da; Sanches, M. F. G. Processing in the quality of Tanzânia grass seeds. Engenharia Agrícola, v.36, p.1157-1166, 2016b. https://doi.org/10.1590/18094430-eng.agric.v36n6p1157-1166/2016

Mendonça, V. Z. de; Mello, L. M. M. de; Pereira, F. C. B. L.; Silva, J. O. da R.; Yano, É. H. Corn production for silage intercropped with forage in the farming-cattle breeding integration. Engenharia Agrícola, v.34, p.738-745, 2014. https://doi.org/10.1590/S010069162014000400013

Quadros, D. G. de; Andrade, A. P.; Oliveira, G. C. de; Oliveira, E. P.; Moscon, E. S. Componentes da produção e qualidade de sementes dos cultivares Marandú e Xaraés de Brachiaria brizantha (Hochst. ex A. Rich.) Stapf colhidas por varredura manual ou mecanizada. Semina: Ciências Agrárias, v.33, p.2019-2028, 2012. https://doi. org/10.5433/1679-0359.2012v33n5p2019

Reynoso, O. R.; Garay, A. H.; Silva, S. C. da; Pérez, J. P.; Quiroz, J. F. E.; Carrillo, A. R. Q.; Haro, J. G. H.; Núñez, A. C. Acumulación de forraje, crecimiento y características estructurales del pasto Mombaza (Panicum maximum Jacq.), cosechado a diferentes intervalos de corte. Técnica Pecuaria en México, v.47, p.203-213, 2009.

Silva, G. Z. da; Martins, C. C.; Cruz, J. de O.; Jeromini, T. S.; Bruno, R. de L. A. Evaluation the physiological quality of Brachiaria brizantha cv. BRS 'Piatã' seeds. Bioscience Journal, v.33, p.572-580, 2017. https://doi.org/10.14393/BJ-v33n3-36519

Silva, V. N.; Arruda, N.; Cicero, S. M.; Maus, C. A.; Giacomeli, R. Morfologia interna e germinação de sementes de arroz de terras baixas produzidas em diferentes regimes hídricos. Irriga, v.19, p.453-463, 2014. https://doi.org/10.15809/irriga.2014v19n3p453

Timbó, A. L. de O.; Pereira, R. C.; Souza Sobrinho F.; Davide, L. C. Nuclear DNA content and chromosome number in Brachiaria spp. genotypes. Revista Ciência Agronômica, v.45, p.62-67, 2014. https://doi.org/10.1590/S1806-66902014000100008

Tomaz, C. de A.; Martins, C. C.; Sanches, M. F. G.; Vieira, R. D. Time reduction for surinam grass seed germination test. Ciência e Agrotecnologia, v.39, p.488-497, 2015. https://doi.org/10.1590/ S1413-70542015000500007

Vargas Junior, F. M. de; Socorro, M. M.; Setti, J. C. de A.; Pinto, G. S.; Martins, C. F.; Costa, J. A. A. da; Magrin, M. N.; Camilo, F. R.; Montagner, D. B. Disponibilidade e valor nutritivo de gramíneas tropicais sob pastejo com ovinos. Archivos de Zootecnia, v.62, p.295-298, 2013. https://doi.org/10.4321/S000405922013000200016

Vigna, B. B. Z.; Jungmann, L.; Francisco, P. M.; Zucchi, M. I.; Valle, C. B. do; Souza, A. P. de. Genetic diversity and population structure of the Brachiaria brizantha germplasm. Tropical Plant Biology, v.4, p.157-169, 2011. https://doi.org/10.1007/s12042-011-9078-1 